\title{
Performance-Based Pay: An Empirical Study in Malaysian Federal Government Linked Companies, Kuching, Sarawak
}

\author{
AZMAN ISMAIL \\ DAYANG NAILUL MUNNA ABANG ABDULLAH \\ NORAZILA ABD. AZIZ \\ AMAT KHAIRULIZAN AMAT ASWADI \\ Faculty of Cognitive Sciences \& Human Development \\ Universiti Malaysia Sarawak \\ MOHD NOOR MOHD SHARIFF \\ College of Business \\ Universiti Utara Malaysia
}

\begin{abstract}
Compensation management literature highlights that properly administering performance-based pay may directly affect employee attitudes and behaviours (i.e. job performance and job turnover). Furthermore, a thorough review of such relationships revealed that the effect of performance-based pay on such employee attitudes and behaviours is indirectly affected by perceptions of procedural justice. The nature of this relationship is less emphasised in past research studies. Therefore, a survey method was used to gather 124 usable questionnaires from employees who have worked in the Malaysian Federal Government linked companies in Kuching, Sarawak (GLCKUCHING). A stepwise regression analysis was performed to determine the mediating effect of procedural justice and the findings obtained indicated that procedural justice and performance-based pay were significantly correlated with job performance. However, no significant correlation was found between procedural justice and performance-based pay with job turnover. Results of this study serve as evidence confirming the assertion that procedural justice does act as a partial mediating variable in the performance-based pay models of the organisational sector investigated. This paper also addresses the implications of such findings on compensation theory and practice. In addition, conceptual and methodological limitations, and directions for future research are also discussed.
\end{abstract}

Keywords: Performance based pay; procedural justice; job performance; and job turnover.

\begin{abstract}
ABSTRAK
Literatur pengurusan pampasan mengketengahkan bahawa ganjaran berdasarkan prestasi yang diuruskan secara teratur boleh mempengaruhi secara langsung sikap dan kelakuan pekerja (prestasi kerja dan keinginan untuk berhenti kerja). Pengamatan yang lebih mendalam terhadap perhubungan tersebut mendedahkan bahawa kesan ganjaran berdasarkan prestasi ke atas sikap dan kelakuan pekerja dipengaruhi secara tak langsung oleh tanggapan keadilan prosedur. Sifat perhubungan ini kurang
\end{abstract}


diberi penekanan dalam kajian lepas. Oleh itu, kaedah tinjauan telah digunakan untuk menggumpul 124 borang soal selidik yang diisi dengan lengkap oleh pekerja di syarikat-syarikat berkaitan kerajaan Persekutuan di Kuching, Sarawak (GLCKUCHING). Keputusan analisa regresi "stepwise” telah menunjukkan dua dapatan penting: pertama, perhubungan di antara ganjaran berdasarkan prestasi dan keadilan prosedur berupaya meningkatkan prestasi kerja. Kedua, perhubungan di antara ganjaran berdasarkan prestasi dan keadilan prosedur tidak berupaya mengurangkan keinginan untuk berhenti kerja. Keputusan kajian ini mengesahkan bahawa keadilan prosedur hanya bertindak sebagai pemboleh ubah mencelah separa (partial mediating variable) dalam model ganjaran berdasarkan prestasi dalam organisasi kajian. Selanjutnya, batasan dan implikasi kajian, serta arah tuju kajian akan datang turut dibincangkan dalam artikel ini.

Kata kunci: Ganjaran berdasarkan prestasi; keadilan prosedur; dan keinginan untuk berhenti kerja.

\section{INTRODUCTION}

Compensation is synonymous to salary and wages, remuneration, reward and/or pay system (Bergman \& Scarpello, 2002; Milkovich \& Newman, 2007). Development of a compensation system in working organisations is traditionally based on variables, such as cost control and internal equity (Henderson, 2006; Kanter, 1989), and the levels and structures of pay for employees are determined based on their job structure, which takes into account aspects such as tenure, seniority, length of service, and membership. Adoption of such pay systems, although may still be appropriate and applicable in manufacturingbased industries which operate in very stable and highly predictable business conditions (Mahoney, 1989, Kanter, 1989; Henderson, 2006), is gradually perceived as insufficient to attract, retain, and motivate good employees to increase organisational productivity (Maurer, Shulman, Ruwe, \& Becherer, 1995).

This shift in perception in terms of what is being valued as pertinent for compensation has subsequently led to the change in many organisations' pay systems from the traditional job-based pay structure to a person-based pay (Lawler, 1995, 2000; Milkovich \& Newman, 2007). In other words, the rules for distributing rewards and the fluctuations of pay levels and structures are now contingent upon the level of performance, skills, knowledge and/or competency exhibited by the employees and not the nature of their job structure (Gomez-Mejia \& Balkin, 1992a, 1992b; Lawler, 1995, 2000; Lee, Law, \& Bobko, 1999). The human resource department must address the implication of this shift, so that the strategies and goals designed for compensation or pay systems are supportive of the goals of organisations (Appelbaum, Bailey, Berg, \& Kalleberg, 2000).

Early studies about performance-based pay systems appeared to place emphasis on the internal properties of the system (Henderson, 2006), and the aspects being explored and examined include definitions, purposes, types, strengths, and weaknesses of the performancebased pay system, as well as the techniques employed to allocate the various types of pay for high performers (Lawler, 1995, 2000). Recent research, however, expands the scope of investigation in order to better understand the effect of performance-based pay systems on employee attitudes and behaviours. For example, adequacy of pay and individual participation in pay systems are considered as salient variables of performance-based pay systems (Henderson, 2006; Kim, 1996, 1999; Milkovich \& Newman, 2007) and proper implementation of these features inevitably may increase job performance and decrease job turnover (Chang \& Hahn, 2006; Greenberg, 2003).

A closer examination of the relationships amongst these features revealed that the effect of 
performance-based pay on job performance and job turnover is indirectly affected by perceptions of procedural justice (Guthrie, 2000; Robbin, Summers, Miller, \& Hendrix, 2000; Roberts, Coulson, \& Chonko, 1999). This finding explains that adequately distributing pay and allowing employees to participate in pay systems will invoke employees' feelings of procedural justice about the systems. As a result, it may lead to increased job performance and decreased job turnover in organisations (Adams, 1963, 1965; Guthrie, 2000; Janssen, 2001).

However, despite all the evidence obtained on aspects affecting the performancebased pay structure, little is known about the mediating role of procedural justice in the performance based pay model in working organisations (Adam, 1963, 1965; Milkovich \& Newman, 2007). Many scholars revealed that procedure justice has been less emphasised in previous studies because research and theoretical development in the field of compensation arises primarily from the economic perspective, which emphasises on the design of pay systems as reactions to market factors of supply and demand (Olson, Schwab, \& Rau, 2000; Ledford \& Hawk, 2000; Rajkumar, 1996). This perspective neglects the influence of human psychological factors, such as procedural justice in affecting the relationship between performance-based pay and individual behaviours and attitudes (Belcher \& Atkinson, 1987; Belcher, Ferris, \& O’Neill, 1985; Rajkumar, 1996).

Besides that, past research studies have much highlighted the characteristics of performance-based pay (e.g., conceptual debate) and neglected multi-disciplinary research approach in compensation management (Belcher \& Atkinson, 1987; Heneman \& Schwab, 1979; Miceli $\&$ Lane, 1991). These conditions fail to capture the dynamic nature of pay system development and decrease the abilities of past research findings to explain how and why performance-based pay affecting attitudinal and behavioural outcomes through perceptions of procedural justice in dynamic organisations (Heneman \& Judge, 2006; Hills, Scott, Markham, \& Vest, 1987; Sturman
\& Short, 2000). The discussion has motivated the researchers to examine the mediating role of procedural justice in the relationship between performance-based pay, and employee attitudes and behaviours that occurs in Malaysian Federal Government linked companies in Kuching, Sarawak (GLCKUCHING).

\section{EXPLANATIONS OF THE CONSTRUCTS}

Performance-based pay, job performance, job turnover, and procedural justice are typically distinct constructs. Performance-based pay is often referred to as provision of additional rewards, on top of employee' basic pay, based on contributions made by the employee (GomezMejia \& Balkin, 1992a, 1992b; Lee, et al., 1999; Milkovich, \& Newman, 2007). This additional reward can include either monetary or nonmonetary incentives given to the employees who exhibit high performance. Job performance covers two major dimensions: task and contextual performance (Bohlander, Snell, \& Sherman, 2001; Eysenck, 1998). Specifically, it may be viewed as a function of the capacity to perform, the opportunity to perform, and the willingness to perform. The capacity to perform relates to the extent to which an employee possesses task-relevant skills, abilities, knowledge, and experiences. The opportunity to perform is viewed as a critical element in the performance process. The willingness to perform is referred to as the degree to which individual employees' desire and will to put high effort in order to meet job performance requirements (Eysenck, 1998). Thus, the combination of those elements may lead to a high employee performance (Gray \& Smeltzer, 1985; Bohlander et al., 2001).

Job turnover, on the contrary, refers to the intention expressed by individuals or employees to leave the organisation without being forced to do so (Mano-Negrin \& Tzafrir, 2004). Price (2001) defined turnover as movement of members across the boundary of an organisation. This 
definition is further strengthened by Abassi dan Hollman (2000), which explains that turnover is the rotation of workers around the labour market, between firm, jobs and occupations. In this study, it is defined as an individual who feels that he/she wants to voluntarily leave his/her organisation. Voluntary turnover can be divided into two categories, one that is avoidable and the other, unavoidable turnover (Heneman \& Judge, 2006; Price, 2001; Stovel \& Bontis, 2002). Avoidable turnover is a situation whereby the intentions of an employee leaving can be prevented by the organisation. It is an action that can be undertaken by the management to foresee and predict the resignation of the employee and through that, formulate a 'lure-back' activity such as a pay raise or new job assignments if the employee is deemed high performing. Unavoidable turnover however, is the event where an employee quits and the resignation could not have been prevented, such as retirement, death, or a pursuit of a new career.

Procedural justice, on the other hand, is often regarded as fairness or equity of the process and procedures used to make allocation decisions (Cropanzano, Byrne, Bobocel, \& Rupp, 2001; Folger, Konovsky, \& Cropanzano, 1992), or "compelling evidence that people consider the nature of their treatment by others as a determinant of fairness" (Greenberg, 1996). In the context of this study, it is defined as individual's perception of justice about the process and system of allocating rewards to high performers. Within the compensation management framework, many scholars think that the constructs are highly interrelated (Alexander \& Ruderman, 1987; Martin \& Lee, 1992; Roberts et al., 1999; Guthrie, 2000). For example, an individual perceives fairness about the communication openness and active participation styles used in the distribution of pays based on performance may lead to increased job performance (Guthrie, 2000; Janssen, 2001) and decreased job turnover (Martin \& Lee, 1992; Roberts et al., 1999; Guthrie, 2000).

\section{CONTEXT OF THE STUDY}

This study was conducted in the three Malaysian Federal Government linked companies
(GLCKUCHING) that operate in Sarawak, whish are Malaysia Airport Sdn. Bhd. (MASB), Pusat Mel Pos Malaysia Berhad (POS), and Telekom Malaysia Berhad (TMB). In these organisations, pay systems are implemented based on broad compensation policies and procedures that have been established by the respective companies' board of directors. Non-executive and executive employees are entitled to get high rewards if they obtain high scores in performance appraisals and have met the key performance indicators set up by the HR departments or divisions of the companies. The decision as to whether the organisation's high performers would be given the extra rewards, either in terms of merit increment, bonus, or promotion are based on the outcome of these assessments. The transparency of the decision-making process and the practice of communication openness in which employees' feedback are accounted and considered throughout the assessment process help ensure acceptance of the pay systems by all in the organisation.

\section{LITERATURE REVIEW}

\section{Relationship between Performance-based Pay, Procedural Justice, and Employee Attitudes and Behaviours}

The mediating role of procedural justice in the performance-based pay models of the studied organisations is consistent with compensation research literature mostly published in US organisational settings. As reported in several well-known research on compensation system in US organisations show that using good treatment styles in the interaction between HR managers/ managers and employees (Greenberg, 1996, 2003; McClurg, 2001; Robbins et al., 2000), such as communication openness (Greenberg, 1996; McClurg, 2001), and allowing employee to participate in the design and administration of pay for performance systems (e.g. merit-based pay and gainsharing plans) which would strongly invoke employee feelings of procedural justice. As a result, it could lead to increased positive personal outcomes, such as increased job performance (Guthrie, 2000; Janssen, 2001) and decreased job turnover (Martin \& Lee, 1992; Roberts et al., 1999; Guthrie, 2000). 
The empirical studies are consistent with the notion of procedural justice theories, namely Leventhal's (1976) self-interest model, Tyler's and Lind (1990) group-value model and Folger et al., (1992) due-process appraisal system. Leventhal's (1976) self-interest model suggested six justice rules for making effective decisions. These are: select decisions based on accurate information, apply consistent allocation procedures, make correct decisions, suppress bias, practise moral and ethical standards in decisionmaking, and ensure allocation process meets recipient expectation and needs.

Besides that, Lind and Tyler's (1988) group-value model suggested that perceptions of procedural fairness are strongly dominated by three types of relational judgements regarding authorities: standing, neutrality, and trust. Standing or status recognition consists of assessments of politeness, treatment with dignity, and respect for rights and entitlements due to every organisational member. Neutrality is the assessment of the degree to which decision-making procedures are unbiased, honest, and able to promote decisions based on evidence. Lastly, trust refers to the assessment of the motives of the decision-maker whether the employees believe that the authority or institution intends to treat people in a fair and reasonable way (Tyler, Degoey, \& Smith, 1996). Thus, Folger et al., (1992) due-process appraisal system suggested at least three justice features should be used for assessing employee performance. These are: adequate notice, fair hearing, and judgment based on evidence.

Relying on these theories, many scholars advocated that opportunities provided to employees for participating in decision making and openly communicating information about the performance-based pay have a positive impact on procedural justice perceptions, and therefore have a positive effect on employee attitudes and behaviours, such as increased job performance (Guthrie, 2000; Janssen, 2001) and decreased job turnover (Martin \& Lee, 1992; Roberts et al., 1999; \& Guthrie, 2000).

The literature was used as a foundation to develop a conceptual framework as shown in Figure 1.

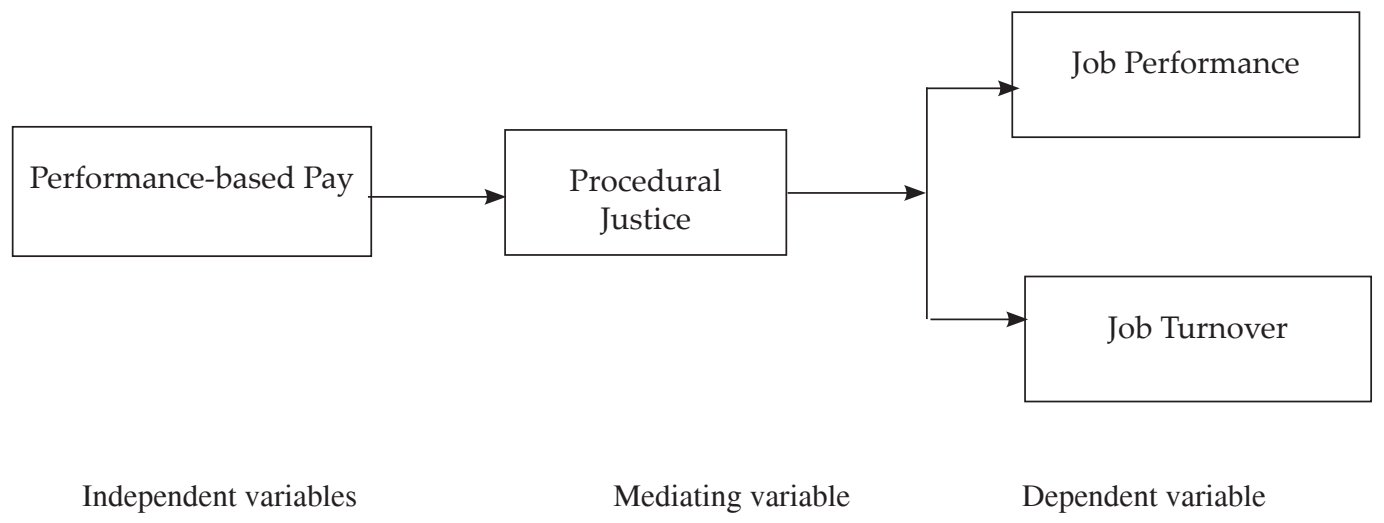

Figure 1: Procedural Justice Positively Mediates the Effect of Performance-based Pay on Individual Attitudes and Behaviours

Based on the above framework, it seems reasonable to assume that fairness of performancebased pay will influence GLCKUCHING employees as this feeling influences Western employees. Procedural justice theories suggested that if GLCKUCHING employees perceive fairness about the process and systems of distributing pays based on performance, this may lead to increased job performance and decreased job turnover. Therefore, it was hypothesised that: 
H1: Procedural justice positively mediates the effect of performance-based pay on job performance

$\mathrm{H} 2$ : Procedural justice positively mediates the effect of performance-based pay on job turnover

\section{METHODOLOGY}

This study used a cross-sectional research design that allowed the researchers to integrate compensation management literature, the in-depth interview, the pilot study, and the actual survey as the main procedure to gather data. The use of such methods may gather accurate and less biased data (Leedy \& Ormrod, 2005; Sekaran, 2000). At the initial stage of data collection, in-depth interviews were conducted with 10 experienced employees in GLCKUCHING. They were one HR manager and three experienced supporting staff who work in MASB, one HR manager and two experienced supporting staff who work in POS, and one HR manager and two experienced supporting staff who work in TMB. Information gathered from such employees helped the researchers to understand the nature of compensation programme, procedural justice features, attitudinal, and behavioural outcomes, as well as the relationship between such variables in the organisations. After refining, categorising, and comparing the interview results with relevant theoretical and empirical evidence, this information was used as a guideline to develop the content of survey questionnaires for a pilot study. Next, the pilot study was done by discussing the survey questionnaires with the above participants in order to verify the content and format of survey questionnaires for an actual study. Their views were used to verify the content and format of actual survey questionnaires. Back translation technique was used to translate the content of questionnaires in the Malay and English Language (Wright, 1996; Hulland, 1999).

The survey questionnaire used was divided into four sections. The first section included six items on performance-based pay that were constructed based on descriptions of performance-based pay in performance literature (Gomez-Mejia \& Balkin, 1992a, 1992b; Lawler, 1995, 2000; Milkovich \& Newman, 2007). The next section included five items on procedural justice that were modified from descriptions found in organisational justice literature (Adams, 1963, 1965; Folger et al., 1992; Leventhal, 1976; Moorman, 1991). The third section listed eight items on job performance adapted from measurement scales developed by Lawler and Hall (1970). The final section included five items on job turnover that were modified from job turnover literature (Martin \& Lee, 1992; ManoNegrin, \& Tzafrir, 2004; Roberts et al., 1999). All the items used in the questionnaires were measured using a 7-item Likert scale ranging from "strongly disagree/dissatisfied" (1) to "strongly agree/satisfied" (7). Information on demographic variables was used as a controlling variable in this study.

The unit of analysis for this study was employees who worked in the MASB, POS and TMB. In the first step of data collection procedure, the researchers met the head of divisions/ departments in the participating companies to find out the rules or procedures for distributing survey questionnaires in their divisions/departments. The population was 840 employees (318 from MASB, 291 from POS, and 231 from TMB). Due to private and confidential reasons, the studied organisations did not allow the researchers to randomly distribute survey questionnaires to their employees who work in different departments. This constraint did not allow the researchers to use probability random sampling technique to gather data from the sample of this study.

Considering the constraints of the GLCKUCHING's rule, a convenience sampling technique was used for data collection. Once permission to conduct the survey was granted, 200 survey questionnaires were then distributed to employees from every department in the organisations through their HR managers. The employees were reassured that their participation in the survey questionnaires would be voluntary, based on their own consent. Of the total number of questionnaire administered, 124 usable questionnaires were returned to the researchers, yielding a $62 \%$ response rate. This figure met the acceptable requirements for inferential statistics (Leedy \& Ormrod, 2005; Sekaran, 2000). The Statistical Package for Social Science (SPSS) version 14.0 was used to assess the psychometric properties of measurement scales and thus test the research hypotheses. 


\section{FINDINGS}

Analysis on gender distribution indicated that there was a greater number of female $(65.3 \%)$ than male $(34.7 \%)$ respondents. The majority of the respondents belong to the 45-54 age group (38.7\%). A large number of respondents had MCE qualification (57.3\%). The majority of respondents were management staff $(84.7 \%)$. Respondents who had worked for less than one year made up the largest group (13.7\%), while the majority of the respondents had salaries between RM1001RM2000 (37.1\%). A summary of the respondents' demographic distribution is presented in Table 1 below.

Table 1: Participant Characteristics $(n=124)$

\begin{tabular}{|c|c|c|c|c|c|}
\hline Gender (\%) & Age $(\%)$ & Education (\%) & $\begin{array}{l}\text { Length of Service } \\
(\%)\end{array}$ & Position (\%) & Monthly Salary (\%) \\
\hline $\begin{array}{l}\text { Male }=34.7 \\
\text { Female }=65.3\end{array}$ & $\begin{array}{l}15-24=11.3 \\
25-34=16.1 \\
35-44=31.5 \\
45-54=38.7 \\
55-64=2.4\end{array}$ & $\begin{array}{ll}\text { Degree } & =14.5 \\
\text { Diploma } & =16.9 \\
\text { STPM } & =5.6 \\
\text { MCE/SPM } & =57.3 \\
\text { SRP/PMR } & =5.6\end{array}$ & $\begin{array}{l}<1 \text { year }=13.7 \\
2-5 \text { years }=10.5 \\
6-10 \text { years }=4.8 \\
11-15 \text { years }=8.9 \\
16-20 \text { years }=8.1 \\
>21 \text { years }=54\end{array}$ & $\begin{array}{l}\text { Executive } \quad=15.3 \\
\text { Leader/Supervisor }=84.7\end{array}$ & $\begin{array}{ll}<\text { RM1000 } & =16.9 \\
\text { RM1001 }-2000 & =37.1 \\
\text { RM2001-3000 } & =34.7 \\
>\text { RM3001 } & =11.3\end{array}$ \\
\hline $\begin{array}{l}\text { SRP/P } \\
\text { SPM/N } \\
\text { STPM: }\end{array}$ & $\begin{array}{l}\text { Lower Cer } \\
\text { Sijil Pelajc } \\
\text { Tingoi Pel }\end{array}$ & $\begin{array}{l}\text { education/Low } \\
\text { Malaysia/Malaysi } \\
\text { n Malaysia/Mala }\end{array}$ & $\begin{array}{l}\text { econdary Assessme } \\
\text { ertificate of Educat } \\
\text { Higher Certificate }\end{array}$ & ducation & \\
\hline
\end{tabular}

Table 2 shows the validity and reliability analyses for measurement scales. The factor analysis with direct oblimin rotation was done for four variables with 24 items. Next, the Kaiser-Mayer-Olkin Test (KMO), which is a measure of sampling adequacy, was conducted for each variable and the results indicated that it was acceptable. Specifically, the results of these statistical analyses showed that (1) all research variables that exceeded the minimum standard of Kaiser-Meyer-Olkin's value of 0.6, were significant in Bartlett's test of sphericity, (2) all research variables had eigenvalues larger than one, (3) the items for each research variable exceeded factor loadings of 0.50 (Hair, Anderson, Tatham \& Black, 1998), and (4) all research variables exceeded the acceptable standard of reliability analysis of 0.70 (Nunally \& Bernstein, 1994). These statistical results confirmed the validity and reliability of measurement scales used for this study.

Table 2: Goodness of Data

\begin{tabular}{lccccccc}
\hline \multicolumn{1}{c}{ Measure } & Items & $\begin{array}{c}\text { Factor } \\
\text { Loadings }\end{array}$ & KMO & $\begin{array}{c}\text { Bartlett's Test } \\
\text { of Sphericity }\end{array}$ & Eigenvalue & $\begin{array}{c}\text { Variance } \\
\text { Explained }\end{array}$ \\
\hline Performance based-Pay & 6 & 0.60 to 0.77 & 0.82 & $253.72, \mathrm{p}=.000$ & 3.21 & 53.47 \\
Procedural Justice & 5 & 0.70 to 0.89 & 0.72 & $430.79, \mathrm{p}=.000$ & 3.59 & 71.85 \\
Job Performance & 8 & 0.58 to 0.81 & 0.86 & $502.34, \mathrm{p}=.000$ & 4.26 & 60.91 \\
Job Turnover & 5 & 0.63 to 0.91 & 0.80 & $299.42, \mathrm{p}=.000$ & 3.17 & 63.48 \\
\hline
\end{tabular}

Table 3 shows that that mean values for the research variables were between 3.3 and 5.4 , indicating that the levels of performance pay, procedural justice, job performance, and job turnover were from moderately high (3) to highest level (7). The correlation coefficients for the relationship between the independent variable (i.e. performance-based pay), the mediating variable (i.e. procedural justice), and the dependent variable (i.e. job satisfaction and job turnover) were less than 0.90 , indicating the data were not affected by a serious collinearity problem (Hair et al., 1998). These results provided further evidence of validity and reliability for measurement scales used in this research (Hair et al., 1998). 
Table 3: Descriptive Statistics and Correlation between Variables

\begin{tabular}{lcccccc}
\hline \multicolumn{1}{c}{ Variable } & Mean & SD & \multicolumn{4}{c}{ Pearson Correlation Analysis } \\
\cline { 4 - 7 } & & & 1 & 2 & 3 & 4 \\
\hline Performance based pay & 4.2 & 1.2 & 1 & & & \\
Procedural Justice & 4.2 & 1.2 & $.66^{* *}$ & 1 & & \\
Job Performance & 5.4 & 1.0 & $.47^{* *}$ & $.46^{* *}$ & 1 & \\
Job Turnover & 3.3 & 1.4 & $-.11(.23)$ & $-.04(.69)$ & $-.14(.13)$ & 1 \\
\hline Note: ${ }^{*} \mathrm{p}<0.05 ; * * \mathrm{p}<0.01=$ Level of Significance Reliabilities represented on diagonal (value 1$)$ & $\mathrm{N}: 124$
\end{tabular}

Pearson correlation analysis was unable to determine the mediating role of distributive justice in the hypothesised model. Stepwise regression analysis was undertaken to test the mediator hypothesis. It can assess the magnitude and direction of each independent variable, and vary the mediating variable relationship between many independent variables and one dependent variable (Foster, Stine, \& Waterman, 1998). According to Baron and Kenny (1986), the mediator variable can be clearly judged when a previously significant effect of predictor variables is reduced to non-significant or reduced in terms of effect size after the inclusion of mediator variables into the analysis.
In this study, research hypotheses that met the mediating testing conditions as suggested by Baron and Kenny (1986) were tested. For example, $\mathrm{H} 2$ was not tested because it did not meet the mediating testing conditions as suggested by Baron and Kenny (1986). Therefore, the outcome of testing $\mathrm{H} 2$ was not been reported in this study. Conversely, H1 was tested using a stepwise regression analysis because it met the mediating testing conditions as suggested by Baron and Kenny (1986). Therefore, the outcome of testing H1 was shown in Table 4.

Table 4: Stepwise Regression Results for Job Performance as a Dependent Variable

\begin{tabular}{|c|c|c|c|}
\hline \multirow[t]{2}{*}{ Independent Variable } & \multicolumn{3}{|c|}{ Dependent Variable } \\
\hline & Step 1 & Step 2 & Step 3 \\
\hline \multicolumn{4}{|l|}{ Controlling Variable } \\
\hline Gender & .05 & -.01 & -.01 \\
\hline Age & .13 & .19 & .18 \\
\hline Education & .08 & .08 & .10 \\
\hline Length of Service & -.37 & $-.37 *$ & $-.35^{*}$ \\
\hline Salary & .32 & $.33^{* *}$ & $.35^{* *}$ \\
\hline Position & -.09 & -.02 & -.02 \\
\hline Independent Variable & & & \\
\hline $\begin{array}{l}\text { Performance based Pay } \\
\text { Mediating Variable }\end{array}$ & & $.47 * * *$ & $.28 * *$ \\
\hline Procedural Justice & & & $.29 * *$ \\
\hline R Squared & .098 & .299 & .345 \\
\hline Adjusted $\mathrm{R}^{2}$ & .052 & .256 & .299 \\
\hline $\mathrm{F}$ & 2.11 & $7.06 * * *$ & $7.6 * * *$ \\
\hline R Square Change & .098 & .201 & .046 \\
\hline F Change $\mathrm{R}^{2}$ & 2.11 & $33.25 * * *$ & $8.04 * *$ \\
\hline
\end{tabular}

Note: $* \mathrm{p}<0.05 ; * * \mathrm{p}<0.01 ; * * * \mathrm{p}<0.001$ 
The table shows the outcomes of hypotheses testing in Step 3: firstly, the relationship between procedural justice and performancebased pay positively and significantly correlated with job performance $(\beta=.29, \mathrm{p}<0.01)$, therefore H1 was supported. This relationship explains that before the inclusion of procedural justice into Step 2, performance-based pay was significantly correlated with job performance $(\beta=.47, \mathrm{p}<0.001)$. As shown in Step 3 (after the inclusion of procedural justice into this step), the previous significant relationship between performancebased pay did not change to become nonsignificant $(\beta=.28, p<0.01)$, but the strength of relationship between performance-based pay and job satisfaction had decreased. This finding demonstrates that procedural justice does act as a mediating variable in the relationship between such variables.

\section{DISCUSSION AND IMPLICATIONS}

The findings of this study showed that procedural justice does act as a mediating variable in the relationship between performance-based pay and job performance, but procedural justice does not act as a mediating variable in the relationship between performance-based pay and job turnover. This result confirms that procedural justice has partially mediated the effect of performancebased pay in compensation management models of GLCKUCHING sector. In this sector, HR managers and/or managers have used the compensation policy and rules set up by the stakeholders to determine the type, level and/or amount of pay to employees who work in the similar and/or different job categories. The majority of the employees perceive that performance-based pay is allocated based on proper procedures, and this has invoked their feelings of procedural justice. As a result, it may lead to increased job performance in the organisations. Conversely, feelings of justice about the process and system of allocating performance-based pay have not led to decreased job turnover in the organisations.

The implications of this study can be divided into three categories: theoretical contribution, robustness of research methodology, and practical contribution. In terms of theoretical contribution, the findings of this study have made two contributions: firstly, performance-based pay indirectly affects job performance via feelings of procedural justice. This result is consistent with studies by Adams (1963, 1965), Guthrie (2000), and Janssen (2001). Secondly, performance-based pay indirectly affects job performance through feelings of procedural justice. This result is not consistent with studies by Martin and Lee (1992), and Roberts et al. (1999). In summary, this study shows that the notion of distributive justice has played a partial mediating role in the compensation management model of GLCKUCHING.

A thorough analysis of the in-depth interview results revealed that the failure of procedural justice to act as a mediating role for the performance-based pay and job turnover relationships might be due to several external factors. Firstly, the nature of the performancebased pay (e.g. pay rises, promotion, and bonus) in recognising only the high achievers may result in those not being recognised, the under performers, to perceive that they had been unfairly treated by the organisations, especially when the repercussions they face due to their underachievement include decisions such as no merit pay, ineligibility for promotion, and disciplinary action. When this happens, the majority of under performers and average performing employees would most likely develop feelings of tension, prejudice, discomfort, and dissatisfaction toward the organisation, prompting them to express an intention to likely leave the organisation.

Secondly, the majority of the employees in the organisations have not been included in the permanent pension scheme. Under this scheme, their income would remain in the national provident funds even when they move to other organisations. However, when this was not the case, they would most likely pursue their employment elsewhere, particularly in organisations that could include such schemes in their employment conditions. Thus, the feeling of dissatisfaction with the organisation pay policy and procedures, such as eligibility for pension scheme, could be a factor that drives them away from their organisations. 
With respect to the robustness of research methodology, the data gathered from compensation management literature, the pilot study, and the survey questionnaire have exceeded the minimum standard for validity and reliability analysis, thus allowing us to produce accurate and reliable findings.

In terms of practical contribution, the findings of this study may be used as guidelines by the management team to improve the design and administration of pay systems in organisations. In order to achieve this objective, communication openness and participation in the design and administration of pay for performance need to be actively implemented by the managerial divisions in the organisation. Those holding these managerial positions, who are overseeing the running of the compensation system, must be trained in interpersonal communication skills, as well as counseling and problem solving skills so that they could better communicate the reasons and justification for compensation to the organisations' employees. In doing so, any misconception pertaining to the system could be addressed and in return, appreciation toward policies and procedures of performance-based pay could be better nurtured. In other words, openness in communication and transparency in compensation decision-making could induce positive attitudinal and behavioural outcomes, thus encouraging employees to support the organisational and human resource department strategies and goals set out for them.

\section{LIMITATIONS}

The conclusion drawn from the results of this study should consider the following limitations. Firstly, a cross-sectional research design was used to gather data one time in the period of study, this could not capture the developmental issues and/or causal connections between variables of interest. Secondly, this study did not provide evidence for the relationship between specific dimensions for the independent variable (performance-based pay), mediating variable (procedural justice), and dependent variable (job performance and job turnover). Thirdly, the outcomes of multiple regression analysis had focused on the level of performance variation explained by the regression equations (Tabachnick \& Fidell, 2001), whereas there are still a number of unexplained factors that need to be incorporated to identify the causal relationship among variables and their relative explanatory power. Finally, the sample for this study was taken from one organisational sector that allowed the researchers to gather data via survey questionnaires. The nature of this sample may decrease the ability of generalising the results of this study to other organisational settings.

\section{DIRECTIONS FOR FUTURE}

The conceptual and methodology limitations of this study need to be considered when designing future research. Firstly, several organisational (e.g. type, ownership, and size) and personal (e.g. gender, position, length of service, and qualification) characteristics should be further explored, to provide meaningful perspectives for understanding how individual similarities and differences affect performance-based pay within an organisation. Secondly, other research designs (e.g. longitudinal studies) should be used to collect data and describe the patterns of change, and the direction and magnitude of causal relationships between variables of interest. Thirdly, to fully understand the effect of performance-based pay features on work attitudes and behaviours via its impact upon feelings of procedural justice, more organisational sectors need to be used as a pay referent in future studies. Fourthly, other theoretical constructs of organisational justice theory, such as interactional justice and distributive justice need to be considered as they have been widely recognised as important links between performance-based pay features and work attitudes and behaviours (e.g. satisfaction, commitment, and ethics) (Greenberg, 1996, 2003; Sweeney \& McFarlin, 1993). Finally, other work attitudes and behaviours of procedural justice such as job performance, turnover, and deviant behaviours that are given more attention in recent compensation research literature should not be fairly considered in a future study (Cohen- 
Charash \& Spector, 2001; Greenberg, 1996, 2003; Milkovich \& Newman, 2007). The importance of these issues needs to be further explained in future research.

\section{CONCLUSION}

Based on the evidence obtained in this study, it is therefore pivotal that current practice within the pay system model considers employees' feelings of procedural justice as a critical aspect of the pay systems. This study further suggests that employees' perception of justice about the process and the systems of allocating pays would likely increase positive attitudinal and behavioural outcomes. Such conditions would subsequently lead the employees to achieve or accomplish the strategies and goals set up by the human resource department in particular, and organisation in general.

\section{REFERENCES}

Abassi, S.M., \& Hollman, K.W. (2000). Turnover...the real bottom line. Public Personnel Management, 2 (3), 333342.

Adams, J.S. (1963). Towards an understanding of inequity. Journal of Abnormal and Social Psychology, 67, 422-436.

Adams, J.S. (1965). Inequity in social exchange. In L. Berkowitz (Ed.). Advances in Experimental Social Psychology, 2. New York: Academic Press.

Alexander, S., \& Ruderman, M. (1987). The role of procedural and distributive justice in organizational behaviors. Social Justice Research, 1, 177-198.

Appelbaum, E., Bailey, T., Berg, P., \& Kalleberg A.L. (2000). Manufacturing Advantage: Why high-performance work systems pay off. Ithaca, NY: Cornell University Press.

Baron, R. M., \& Kenny, D. A. (1986). The moderator-mediator variable distinction in social psychological research: Conceptual, strategic, and statistical considerations. Journal of Personality and Social Psychology, 51, 11731182.

Belcher, D.W., \& Atchison, T. (1987). Compensation administration. Englewood Cliffs, NJ: Prentice Hall.

Belcher, D.W., Ferris, N.B., \& O’Neill, J. (1985). How wage surveys are being used. Compensation and Benefits Review, 17 (4), 34-51.

Bergmann, T.J., \& Scarpello, V.G. (2002). Compensation decision making. Australia: South-Western Thomson Learning.

Bohlander, G., Snell, S., \& Sherman, A. (2001). Managing human resources. Australia: South-Western College Publishing.

Chang, E., \& Hahn, J. (2006). Does payfor-performance enhance perceived distributive justice for collectivistics employees? Personnel Review, 35 (4), 397-412.

Cohen-Charash, Y., \& Spector, P.E. (2001). The role of justice in organization: A meta-analysis. Organizational Behavior and Human Decision Processes, 86, 278-324.

Cropanzano, R., Byrne, Z. S., Bobocel, D. R., \& Rupp, D. R. (2001). Moral virtues, fairness heuristics, social entities, and other denizens of organizational justice. Journal of Vocational Behavior, 58, 164-209.

Eysenck, M. (1998). Psychology: An integrated approach. New York: Addison-Wesley Longman Ltd.

Folger, R., Konovsky, M.A., \& Cropanzano, R. (1992). A due process metaphor for performance appraisal. Research in Organizational Behavior, 3, 129-177.

Foster, D.P., Stine, B., \& Waterman, R. (1998). Business analysis using regression: A casebook. Springer-Verlag.

Gomez-Mejia, L.R., \& Balkin, D.B. (1992a). Compensation, organizational strategy, and firm performance. Cincinnati, $\mathrm{OH}$ : South Western Publishing Co.

Gomez-Mejia, L.R., \& Balkin, D.B. (1992b). The determinants of faculty pay: An 
agency theory perspective. Academy of Management Journal, 35 (5), 921-955.

Gray, E.R., \& Smeltzer, L.R. (1985). SRM forum: Corporate image Review, 24 (4), 73$78,2$.

Greenberg, J. (1996). The quest for justice on the job: Essays and experiments. Thousand Oaks, CA: Sage.

Greenberg, J. (2003). Creating unfairness by mandating fair procedures: The hidden words of a pay-for-performance plan. Human Resource Management Review, 13, 41-57.

Guthrie, J.P. (2000). High involvement work practices, turnover, and productivity: Evidence from New Zealand. Academy of Management Journal, 44 (1), 180190.

Hair, J. F., Anderson R. E., Tatham, R. L., \& Black, W. C. (1998). Multivariate data analysis. New Jersey: Prentice Hall.

Henderson, R.I. (2006). Compensation management in a knowledge basedworld. New Jersey: Prentice-Hall.

Heneman, H.G., \& Judge, T.A. (2006). Staffing organization. New York: McGrawHill.

Heneman, H.G., III, \& D.P. Schwab. (1979). Work and rewards theory. In D. Yoder and H.G. Henneman, Jr. (Eds.). ASPA Handbook of Personnel and Industrial Relations.

Hills, F., Scott, D., Markham, S., \& Vest, M. (1987). Merit Pay: Just or Unjust Desserts. Personnel Administrator, 32, 53-64.

Hulland, J. (1999). Use of partial least square (PLS) in strategic management research: A review of four recent studies. Strategic Management Journal, 20 (2), 195-204.

Janssen, O. (2001). Fairness perceptions as a moderator in the curvilinear relationships between job demands, and job performance and job satisfaction. Academy of Management Journal, 44 (5), 1039-1050.

Kanter, R.M. (1989). When giants learn to dance mastering the challenges of strategy, management and careers in the 1990s. Routledge, London:
Kim,D.O.(1996).Factors influencing organizational performance in gainsharing programs. Industrial Relations, 35 (2), 227-44.

Kim, D.O. (1999). Determinants of the survival of gainsharing programs. Industrial and Labor Relations Review, 53 (1), 21-38.

Lawler, E.E. (1995). Choosing an involvement strategy. Academy of Management Executive, 2, 197-203.

Lawler, E.D. (2000). Rewarding excellence: Pay strategies for the new economy. California: Jossey-Bass.

Lawler, E.E., \& Hall, D.T. (1970). Relationship of job characteristics to job involvement, satisfaction and intrinsic motivation. Journal of Applied Psychology, 54, 305-312.

Ledford, G.E., \& Hawk, E.J. (First Quarter 2000). Compensation strategy: A guide for senior managers. ACA Journal, 9 (1). 28-38.

Lee, C., Law, K.S., \& Bobko, P. (1999). The importance of justice perceptions on pay effectiveness: A two-year study of a skill-based pay plan. Journal of Management, 25 (6), 851-873.

Leedy, P.D., \& Ormrod, J.E. (2005). Practical research: Planning and design. Pearson Education Ltd.

Leventhal, G.S. (1976). Fairness in social relationships. In J.T. Spence, \& R.C. Carson, (Eds.). Contemporary Topics in Social Psychology. Morristown, New Jersey: General Learning Press, 211-240.

Mahoney, T.A. (1989). Employment compensation planning and strategy. In L.R. GomezMejia (Ed.). Compensation and Benefits, Bureau of National Affairs, Washington, DC, 1-28.

Maurer, J.G., Shulman, J.M., Ruwe, M.C., \& Becherer, R.G. (1995). Encylopedia of Business. New York: Gale Research.

Martin, J.E., \& Lee, R.T. (1992). Pay knowledge and referents in a tiered-employment setting. Industrial Relations (Canadian), 47 (4), 654-671.

McClurg, L.N. (2001). Team rewards how far have we come? Human Resource Management, 40 (1), 73-86. 
Miceli, M.P., \& Lane, M.C. (1991). Antecedents of pay satisfaction: A review and extension. Personnel resources management, 9, 235-309.

Milkovich, G.T., \& Newman, J.M. (2007). Compensation. New York: McGraw Hill.

Mano-Negrin, R., \& Tzafrir, S.S. (2004) Job search modes and turnover. Career Development International, 9 (5), 442458.

Moorman, R.H. (1991). Relationship between organizational justice and organizational citizenship behaviors: Do fairness perceptions influence employee citizenship? Journal of Applied Psychology, 76, 845-855.

Nunally, J.C., \& Bernstein, I.H. (1994). Psychometric theory. New York: McGraw Hill.

Olson, C.A., Schwab, D.P., \& Rau, B.L. (2000, January). The effects of local market conditions on two pay-setting systems in the federal sector. Industrial and Labor Relations Review, 53 (2), 272-195.

Price, J.L (2001). Reflections on the determinants of voluntary turnover. International Journal of Manpower, 22 (7), 600-624.

Rajkumar, K. (1996). Paying for performance: Designing effective compensation strategies. Malaysia: Pelanduk Publications (M) Sdn. Bhd.

Robbins, T.L., Summers, T.P., Miller, J.L., \& Hendrix, W.H. (2000). Short research note using the group-value model to explain the role of noninstrumental justice in distinguishing the effects of distributive and procedural justice. Journal of Occupational and Organizational Psychology, 73, 511-518.

Roberts, J.A., Coulson, K.R., \& Chonko, L.B. (1999). Salesperson perceptions of equity and justice and their impact on organizational commitment and intent to turnover. Journal of Marketing Theory and Practice, 1-16.

Sekaran, U. (2000). Research methods for business: A skill building approach. New York: John Wiley and Sons, Inc.
Stovel M., \& Bontis, N. (2002). Voluntary turnover: Knowledge management friend orfoe? Journal of Intellectual Capital, 3 (3), 303-322.

Sturman, M.C. \& Short, J.C. (2000). Lump-Sum Bonus Satisfaction: Testing the construct validity of a new pay satisfaction dimension. Personnel Psychology, 53 (3), 673-700.

Sweeney, P.D., \& McFarlin, D.B. (1993). Workers' evaluation of the "ends" and the "means": An examination of four models of distributive and procedural justice. Organizational Behavior and Human Decision Processes, 55, 23-49.

Tabachnick, B.G., \& Fidell, L.S. (2001). Using multivariate statistics. Sydney: Allyn and Bacon.

Tyler, T.R., Degoey, P., \& Smith, H. (1996). College students' perceptions of the acceptability of below average salary offers. Journal of Vocational Behavior, 196-208.

Tyler, T.R, \& Lind, E.A. (1990). Intrinsic versus community-based matter? Journal of Social Issues, 46, 83-94.

Wright, L.L. (1996). Qualitative international management research. In B.J. Punnett, O. Shenkar (Eds.), Handbook for International Management Research. Oxford, UK: Blackwell Publishers Inc. 